\title{
Basic Positive Duties of Justice and Narveson's Libertarian Challenge
}

Pablo Gilabert Concordia University

\begin{abstract}
Are positive duties to help others in need mere informal duties of virtue or can they also be enforceable duties of justice? In this paper I defend the claim that some positive duties (which I call basic positive duties) can be duties of justice against one of the most important principled objections to it. This is the libertarian challenge, according to which only negative duties to avoid harming others can be duties of justice, whereas positive duties (basic or nonbasic) must be seen, at best, as informal moral requirements or recommendations. I focus on the contractarian version of the libertarian challenge as recently presented by Jan Narveson. I claim that Narveson's contractarian construal of libertarianism is not only intuitively weak, but is also subject to decisive internal problems. I argue, in particular, that it does not provide a clear rationale for distinguishing between informal duties of virtue and enforceable duties of justice, that it can neither successfully justify libertarianism's protection of negative rights nor its denial of positive ones, and that it fails to undermine the claim that basic positive duties are duties of global justice.
\end{abstract}

\section{Introduction}

Are positive duties to help others in need mere informal duties of virtue or can they also be enforceable duties of justice? ${ }^{1}$ In this paper I defend the claim that some positive duties (which I call basic positive duties) can be duties of justice against one of the most important principled objections to it. This is the libertarian challenge, according to which only negative duties to

Pablo Gilabert is assistant professor of philosophy at Concordia University, Montreal. He is currently working on articles on global justice, multiculturalism, and Kant's practical philosophy. Some recent publications are "The Duty to Eradicate Global Poverty: Positive or Negative?" (Ethical Theory and Moral Practice, 2005), “A Substantivist Construal of Discourse Ethics (International Journal of Philosophical Studies, 2005), and "Considerations on the Notion of Moral Validity in the Moral Theories of Kant and Habermas" (Kant-Studien, 2005). 
avoid harming others can be duties of justice, whereas positive duties (basic or nonbasic) must be seen, at best, as informal moral requirements or recommendations. I focus on the contractarian version of the libertarian challenge as recently presented by Jan Narveson. ${ }^{2}$ I proceed as follows. First, I clarify some concepts central to our discussion, such as the notions of negative and positive duties, basic and nonbasic positive duties, perfect and imperfect duties, duties of virtue and duties of justice, and domestic and global duties (section 2). Next, I reconstruct Narveson's construal of the libertarian challenge (sections 3 and 4), and then show that it is seriously flawed (section 5). Narveson's contractarian construal of libertarianism is not only intuitively weak but is also subject to decisive internal problems. I argue, in particular, that it does not provide a clear rationale for distinguishing between informal duties of virtue and enforceable duties of justice, that it can neither successfully justify libertarianism's protection of negative rights nor its denial of positive ones, and that it fails to undermine the claim that basic positive duties are duties of global justice.

\section{Some Preliminary Definitions}

Before addressing the libertarian challenge to the claim that there can be basic positive duties of justice, it is important to clarify what the alleged category of "basic positive duties of justice" is. I do this by means of a set of distinctions. The first is the distinction between negative and positive duties. To say that an individual $A$ has a negative duty to another individual $B$ with respect to a certain object $O$ is to say that $A$ ought not to harm $B$ by depriving them of access to $O$. $A$ harms $B$, for example, when $A$ rapes $B$, as $B$ is thereby deprived of access to physical integrity. To say, on the other hand, that $A$ has a positive duty to $B$ with respect to $O$ is to say that $A$ ought to assist $B$ in gaining or maintaining access to $O$. $A$ fulfills a positive duty to $B$ when, for example, $A$ takes $B$ to the hospital in an emergency, thereby assisting $B$ in gaining access to (the restoration of) a healthy condition.

A second important distinction is that between basic and nonbasic positive duties. This distinction ranges over the objects of positive duties. A basic positive duty is one focused on objects, access to which is a necessary condition for the recipient to live a minimally decent life. A nonbasic duty is one whose object is above the threshold of what is necessary to live a minimally decent life. Identifying the set of objects belonging to the category of basic positive duties is, of course, a matter of controversy. We may have different accounts of what a (minimally or otherwise) decent life is. However, most of us will agree that such a life would at least include access to food and water, health care, education, and housing. Someone who does not 
have access to such goods can be characterized as destitute, needy, or severely poor. In the remainder of this paper, I will assume that basic positive duties are duties to do one's fair share in assisting others in gaining and maintaining access to this minimal set of objects satisfying their most basic needs. ${ }^{3}$ To simplify the discussion, I will also assume that the beneficiaries of these duties are not responsible for their condition of need.

There are two further distinctions that will be crucial for our discussion. These are the distinction between perfect and imperfect duties, on the one hand, and between duties of justice and duties of virtue, on the other. These two distinctions are often conflated. But I think that it is important to keep them separate. The distinction between perfect and imperfect duties is the following. $A$ has a perfect duty to $B$ with respect to $O$ when it is clear that $B$ has a claim against $A$ as to when and how $A$ has to fulfill such obligation. Thus, if the duty is negative, we know when and how it is that $A$ is not to deprive $B$ of access to $O$. If the duty is positive, we know when and how it is that $A$ is (to do their fair share in order) to provide $B$ with access to $O$. When a duty is imperfect, we cannot say that $B$ has a precise claim against $A$ with respect to $O$, as we cannot say when or how $A$ is to fulfill their duty. Imperfect duties afford duty-bearers significant latitude as to when and how they are fulfilled. The duty to be generous with other people is an example of an imperfect duty. We must be generous with others in some cases and to some extent. But no one can claim, in any given occasion, that we be generous with them. The duty not to rape is, on the other hand, a perfect duty. It is clear that anyone has a claim against you that you do not rape them at any time.

I said that we should not conflate the distinction between perfect and imperfect duties with the distinction between duties of virtue and duties of justice. The reasons are twofold. The first is that not all perfect duties might be said to be duties of justice. For a duty to be a duty of justice, it must not only involve a claim on the part of the recipient, but that claim must also be an enforceable one. More precisely, when we talk about the distinction between virtue and justice, we talk about the distinction between informal interpersonal duties and duties we have, in principle, reason to hold as legally enforceable if their legal enforceability is necessary for their fulfillment. Thus, the duty not to break a promise might be a perfect duty, but we may not want to consider all of its instances as being legally enforceable (though we may select a subset of them as so being, such as in the case of contracts involving transference of property). Justice ranges over particularly important duties whose fulfillment we are prepared to secure by means of public coercion. Duties of justice have, as a correlate, certain rights (i.e., justifiably enforceable claims). If $A$ has a duty of justice to 
$B$ with respect to $O$, then $B$ has a right against $A$ regarding $A$ 's fulfillment of their requirements with respect to $O{ }^{4}$

The second reason for avoiding a conflation between the imperfect/perfect and virtue/justice distinction is that we may face situations in which certain general duties are imperfect but should be made perfect as a result of recognizing their relevance from the point of view of justice. The protection of people against serious physical harm by others may be said to be a duty of justice, in the sense that it is focused on guaranteeing people's access to an extremely important object (physical integrity) and that we have, in principle, reason to secure its fulfillment by coercive means if necessary. However, it may not be clear who should do what in order to implement this duty of protection, and thus the recipients of protection have no precise claim against specific individuals. The negative duty not to physically assault others is a perfect one. But the duty to protect people from physical assault is not. Any individual might have latitude to decide whom to protect and how to protect them. However, given the reasons of justice mentioned, we must recognize the obligation to develop institutional structures clearly specifying some forms of protection and, thus, make the claim to protection more precise. These structures would generate, out of the general duty to protect, which is imperfect, a set of specific duties, which are perfect (such as the duties of policemen and lawyers, the duties of taxpayers to sustain the public institutions dealing with security, and so on). Thus, imperfect duties are dynamic and can be partly specified as perfect duties once their status as duties of justice is recognized. ${ }^{5}$

The core contentious issue to be addressed here is whether there are basic positive duties that can be deemed duties of justice. For this to be the case, we must show that there are good reasons for taking them to involve correlative rights on the part of the needy. Libertarians deny that this can be done. In what follows, we will consider Narveson's case for such denial. But before addressing the libertarian challenge, I should mention one last distinction, this time focused on the scope of duties (i.e., on their domain of application). This is the distinction between domestic and global duties. Global duties are those that apply to all human beings who can be agents or recipients of them, ${ }^{6}$ whereas domestic duties are those that range over relations between compatriots. This distinction is not so central for libertarians like Narveson, who assume that claims of justice are in principle universal, made by anyone against everyone else.

\section{The Libertarian Challenge}

The general question before us is: Do we have reason to see some basic positive duties as duties of justice? An affirmative 
answer to this question needs to show that basic positive duties can be made perfect and be seen as having correlative rights. The first part of the answer poses no serious conceptual problem, though it does demand a careful discussion of efficient and fair institutional mechanisms. Basic positive duties to do our fair share to contribute to the satisfaction of others' basic needs can be made perfect if we identify subjects in need and agents able to contribute to their satisfaction without unreasonable sacrifice on their part. The second part of the answer is less easy to articulate. It is clear that we can articulate a set of socioeconomic rights. Article 25 of the 1948 Universal Declaration of Human Rights mentions a set of rights to have basic needs met. Some national constitutions (such as the French and the South African constitutions) state socioeconomic rights, and forms of legislation have been developed to specify modes of fulfillment of them. There is, then, no conceptual impossibility of articulating socioeconomic rights focused on basic needs as correlated with certain sets of duties on the part of individuals and governments. These duties, given the specification of the correlative rights and forms of fulfillment, can thereby be seen as perfect and enforceable (i.e., as duties of justice). The most serious question is not whether this construal is coherent but whether it is justifiable on substantive grounds. Defenders of basic socioeconomic rights say that their satisfaction must be advocated by any reasonable conception of justice that recognizes the moral importance of the urgent interest of all humans in having access to the most basic conditions of a minimally decent life. Libertarians, however, deny that these right claims can be justified. ${ }^{7}$

The central libertarian complaint against enforcement of positive duties (basic or nonbasic) is that it involves violation of people's right to do whatever they want with what is rightfully theirs (as long as they do not thereby harm other people). A classical formulation of this claim is given by Robert Nozick. According to Nozick, positive duties cannot be duties of justice as well as duties of virtue because their enforcement involves an unacceptable "continuous interference with people's lives." Such continuous interference is unavoidable if basic positive duties are to be enforced (for example by means of taxation) against the will of resourceful people who do not want to contribute to improving the condition of those in need. The only contribution compatible with the right to dispose freely of what is rightfully ours is voluntary transference in accordance with the slogan "from each as they choose, to each as they are chosen."9

Nozick's construal of the libertarian challenge has been subject to several criticisms. I will not rehearse them here. ${ }^{10}$ The debate between Nozickean libertarians and their liberal and socialist opponents seems to have reached an impasse. The 
former appeal to the intuition that nobody can be forced to comply with demands that are positive rather than negative unless such demands amount to compensation for previous harms for which the addressees of the demands are causally responsible. The latter, on the other hand, appeal to the intuition that a just society must introduce mechanisms (even coercive ones) compensating those who are disadvantaged due to natural or social circumstances beyond their control. According to liberal and socialist philosophers, the second intuition is sufficient for grounding some limitations to the economic freedom of resourceful people, whereas for Nozickean libertarians the first intuition supports absolute "side constraints" against any limitation of individuals' property rights. Narveson's construal of the libertarian challenge is peculiar in that it attempts to overcome this impasse by appealing to a contractarian framework of normative justification capable of arbitrating the conflict between these (and other) intuitions.

\section{Narveson's Construal of the Libertarian Challenge}

Unlike Nozick, Narveson suggests that we reach the conclusion that only negative duties can be duties of justice without appealing to any normative intuitions. Narveson's strategy is to ground the libertarian claim by appealing to a contractarian framework based on a criterion of "mutual advantage," according to which we should follow only those norms to which rational persons would agree, given some "obvious, normal facts about people and their situations." 11 This line of argument is, according to Narveson, of a universalist nature, yielding rules for all human beings. The libertarian claim that only negative duties are duties of justice is thus a claim whose scope is both domestic and global.

To unpack Narveson's argument, we can start by quoting and refining his core claims as helpfully stated in the abstract of his article "Welfare and Wealth."12 They are the following:

[A1] "There is no sound basis for thinking that we have a general and strong duty to rectify disparities of wealth around the world, apart from the special case where some become wealthy by theft or fraud."

[A2] A "rational morality" must be "built on the interests of all."

[A3] Such interests "include substantial freedoms, but not substantial entitlements to others' 'assistance'."

[A4] "The situation of the world's poor is not that of victims of disasters, but simply of less-developed technology, which can be repaired by full and free trade relations with others." 
[A5] "The true savior of the world's poor is the businessman, not the missionary. What we need to do is to strike down barriers to commerce, rather than requisition 'aid'."

To focus our discussion, the following clarifications are necessary. First, theses [A4] and [A5] are largely empirical claims. I will address them briefly at the end of this paper, but for the most part my focus will be on [A1]-[A3]. My main question is whether assisting people for whose poverty neither we nor they are clearly responsible is a duty of justice. [A1] says that this would not be the case.

[A1] denies that general positive duties to rectify disparities of wealth around the world can be strong enough to be deemed duties of justice. The grounds for this denial are briefly outlined in [A2] and [A3]. [A2] announces Narveson's view of the foundations of normative argument, which he identifies with mutual advantage contractarianism. [A3], on the other hand, is the general normative claim yielded by applying [A2] (given the "obvious, normal facts about people and their situations") and grounding [A1]. [A3] simply states the central normative libertarian principle that only negative duties have correlative entitlements (i.e., rights) in the contractarian language focused on "the interests of all."

Since our focus will be neither the eradication of poverty in general nor the elimination of wealth disparities, but the reasonable assistance on the part of wealthy people to those who suffer severe poverty due to lack of satisfaction of basic needs, a more circumscribed version of [A1] will be addressed, namely:

[A1*] There is no sound basis for thinking that we have a basic positive duty of justice to assist those in need when we can at no grievous cost to ourselves unless we are causally responsible for their condition of need.

Narveson himself argues for something like [A1*] in his article "We Don't Owe Them a Thing!" where he claims that the duty to help those in need (the severely poor who are very badly off) when we can do it at no grievous cost to ourselves is not an "enforceable duty" of justice but only at best a duty of virtue that falls "beyond strict justice."13 The argument for this claim is, again, an appeal to what rational persons would agree to when setting up a "social contract" selecting mutually advantageous rules of interaction.

Let us examine in some detail Narveson's use of the contractarian standard of normative justification to defend the libertarian conception of justice. The central puzzle here is whether a morality of mutual advantage would ground a conception of justice focused only on negative duties. Why would basic positive duties not be recognized as enforceable obligations of jus- 
tice? Narveson's answer is that a morality of mutual advantage would yield, as an account of what can be coercively enforced, only a set of negative rights. To assess this answer, we need first to clarify (1) Narveson's account of what a morality of mutual advantage is; (2) his view that negative duties can be duties of justice; (3) his claim that positive duties, including basic ones, cannot be duties of justice; and (4) his view of virtue and justice as having cosmopolitan scope.

\subsection{Narveson's contractarianism}

Narveson claims that the test for the correctness of a norm is not whether it fits someone's intuitions. We have different intuitions, and it is not clear that appealing to them will provide reasons that someone who does not have them would accept. We can assume that "people are more or less rational, in a public sense-they are capable of addressing intelligible claims and statements to each other, in the hope or expectation that they will be accepted by those to whom they are addressed." But we cannot assume that their "interests, desires, values," in short their "utilities," immediately converge. Given this fact of widespread evaluative disagreement and the obvious environmental fact that there are not enough resources to fully satisfy everyone's interests, we need a mechanism for reaching rational agreements that does not assume what we do not yet have. ${ }^{14}$ Such mechanism is, according to Narveson, what the standard of "mutual advantage" provides:

Mutual advantage says, simply, that a configuration which is better for all relevant actors, and no worse for anyone else, is morally preferable to one which is not, unless there is a prior wrong to correct. ${ }^{15}$

In defending this standard, Narveson appeals to the "profound" "Pareto idea" requiring that "no one 'lose'."16 The Pareto idea is commonly used to compare different states of affairs in terms of their impact on people's interests (or "utilities"). This idea has in fact two versions, a strong one and a weak one. According to the strong version, a state of affairs $\mathrm{X}$ in which there is generalized compliance with a rule $R$ is superior to another state of affairs $\mathrm{Y}$ where there is not generalized compliance with $\mathrm{R}$ if everyone is better off (in terms of their "utilities") in X than in Y. According to the weak version, X is superior to $\mathrm{Y}$ if at least one person is better off and no one is worse off. In his presentation of the standard of mutual advantage quoted above, Narveson seems to focus on the strong version of the Pareto idea. The contractarian view he defends says that a rule is correct if it is rationally acceptable to those affected by it, and this just means that the parties involved can 
see a situation of general compliance with the rule as Pareto superior (in the strong sense) to the alternatives. At some points Narveson's approach seems, however, to be flexible between the different versions of the Pareto idea, allowing for degrees.

The obvious direction is up: we want the rules to enable all to advance, and at a minimum to prevent people from being pushed in the wrong direction, backward. It seems to me that this classical case is enormously strong, and not of a type that can be seriously shaken by appeals to intuition. ${ }^{17}$

\subsection{Negative duties as duties of justice}

How can people seek beneficial outcomes from their interactions with other people? There are several legitimate ways of doing this, according to Narveson. These include avoiding others when interaction with them would be detrimental and attempting to get them to benefit us by asking for their help or by offering a mutually beneficial joint venture (such as a market transaction involving the exchange of desirable goods). ${ }^{18}$ What we cannot do, according to Narveson, is to exact benefits from others by means of coercion. When it comes to the use of coercion, "the indicated rule is: Do not! Do not, that is, unless it is necessary in order to ward off or defend oneself or others from persons violating this very rule."19

Narveson's justification of this rule, which he calls "the basic principle of right," is brief:

Why is this the indicated rule? The reasoning is familiar since Hobbes at least. Any normal person can do this sort of thing, every normal person (and almost all others) would be very adversely affected by others' doing it, and the obvious agreement is to rule it out. General resort to force makes life worse for all. ${ }^{20}$

A contractarian approach would then ground the principle of right according to which no force can be used on others unless it is required as a response to their own use of force. This principle is justifiable because a situation in which it is not recognized would be worse for all, as all share the strong interest in not being coerced by others (i.e., would be "very adversely affected" by others' use of coercion against them).

\subsection{Positive duties might be duties of virtue, but cannot be duties of justice}

The principle of right accepts coercion only if it is necessary to protect negative rights or to secure rectification for their violation, and thus as enforcement of negative duties. This is in tune with Narveson's libertarianism, according to which "we all have 
one single, fundamental right—-the right to liberty." ${ }^{21}$ Narveson denies that coercion can be also used to secure compliance with positive duties. He recognizes that help to others in need when the costs to the contributors would not be too high is something that we should recognize as a demand of moral virtue. But he does not see it as a demand of justice. Enforcing positive duties would be inconsistent with the libertarian principle of right according to which only negative rights can be coercively protected.

Our fundamental right to liberty is negative, not positive. The reasoning behind that is straightforward. A positive right, by definition, cuts further into our liberty than the corresponding negative one: if you are forced to help others in need, then you do not have your choice whether to help them. Yet your not helping them does not cut into the liberty of the victims: it does not disenable them from doing whatever they can do anyway-which, to be sure, is not much. But it does not worsen their situations as compared with what they are at the time when action could take place. Instead, it merely leaves them no better off. ${ }^{22}$

Libertarianism "denies that we owe assistance to anyone." Positive claims to receive assistance are not coercively enforceable. They are, at best, "reinforceable" (subject to informal practices of encouragement and criticism).$^{23}$

\subsection{Global scope}

Narveson sees the points discussed in 4.1 through 4.3 as having universal, or cosmopolitan, scope. The duty not to harm others is universal, owed to distant others as well as to fellow nationals. The duty to assist others in need is neither enforceable domestically nor globally. It is, however, a duty of virtue whose scope is in principle universal. The only case in which helping distant others is not (or is less) morally mandatory is when higher costs are involved. "Although distance usually makes a difference in cost, when it doesn't, distance has no differential effect on our duties." 24

\section{Defending Basic Positive Duties of Justice Against Narveson's Challenge}

There is much in Narveson's challenge that warrants critical scrutiny. In his recent response to Narveson, Larry Temkin points out, quite convincingly in my view, that Narveson has failed to portray egalitarian conceptions of justice in a fair way, and thus much in his criticism of them is beside the point. Temkin has also shown that Narveson's dismissal of the appeal to intuitions fails to recognize the extent to which contractar- 
ianism itself relies on intuitions (for example, on the "profound" "Pareto idea" as bedrock for judging moral improvements). Finally, Temkin argues that positive duties to assist those for whose condition of need we are not responsible may be considered demands of justice once we recognize that there are some nonagent relative standards of assessment. Temkin does not, however, "claim that we [the relatively wealthy] owe the world's poor aid, at least if that implies that they have a right to such aid." 25 Temkin thus leaves Narveson's crucial thesis that the needy do not have rights to assistance by those who can contribute at no grievous cost to themselves untouched. In what follows, I challenge Narveson's thesis that there are no basic positive rights. This is, after all, perhaps the central controversial claim by libertarians and needs to be addressed directly.

\subsection{Intuitive complaints}

A common critique of mutual advantage contractarian conceptions of justice is that they lead to counterintuitive results. According to mutual advantage contractarianism, $A$ and $B$ have reason to accept a rule $\mathrm{R}$ when $\mathrm{R}$ is mutually advantageous to them. Assume, however, that $A$ is quite wealthy and strong and that $B$ is weak and starving. Since $B$ would neither be able to greatly benefit nor seriously harm $A$, it is not obvious that $A$ would rationally agree to $\mathrm{R}$ if $\mathrm{R}$ demands that $A$ contribute to the satisfaction of the basic needs of $B$. $A$ would prefer alternative rules. Examples would be $\mathrm{R}^{*}$, under which $A$ is allowed to let $B$ starve to death, or $\mathrm{R}^{* *}$, under which $A$ can offer $B$ a job whose result is great profit for $A$ and a very bad salary for $B$. Since neither under $\mathrm{R}^{*}$ nor under $\mathrm{R}^{* *} A$ makes $B$ 's condition worse (and in fact under $\mathrm{R}^{* *} B$ 's condition is improved), it is not wrong for $A$ to accept $\mathrm{R}^{*}$ or $\mathrm{R}^{* *}$ instead of $R$. These outcomes, of which there are unfortunately plenty of historical examples, seem intuitively repugnant. ${ }^{26}$ The reason is that they assume an uncritical recognition of the bargaining power of the wealthy and strong when its use involves complete disregard for the predicament of the poor and weak (as is the case in $\mathrm{R}^{*}$ ), or their exploitation (as is the case in $\mathrm{R}^{* *}$ ). As Brian Barry forcefully put it, "justice as mutual advantage fails egregiously to do one thing that we normally expect a conception of justice to do, and that is provide some moral basis for the claims of the relatively powerless." 27

I find this intuitive argument compelling. But Narveson and other mutual advantage contractarians might not be moved by it. They would, in fact, say that it is question begging. Intuitions, for them, cannot be used to challenge the results of a contractarian argument because the latter is precisely introduced in order to arbitrate clashes of disparate intuitions. One can, and I think must, respond to this rebuttal by appealing to 
Rawls's idea of "reflective equilibrium," showing that contractarian procedures and intuitive judgments interact rather than being unilaterally foundational with respect to each other. ${ }^{28}$ In what follows I want, however, to provide a more internal criticism of Narveson's rejection of basic positive duties of justice. I will show that even on its own terms, the contractarian proposal, as presented by Narveson, fails to provide a decisive argument.

\subsection{From duties of virtue to duties of justice}

A first internal problem with Narveson's approach is that it does not tell us clearly what sorts of considerations should determine our viewing a duty as one of justice besides one of virtue. Narveson does say that a duty of justice involves coercively enforceable rights, but he does not clearly tell us in virtue of what a duty should be seen as having such correlative rights. By analyzing his texts we find, however, two sets of considerations aimed at showing that negative duties have, unlike basic positive duties, the privilege of being also duties of justice. Both considerations fail, however, to show that (at least basic) positive duties should not also be seen as duties of justice.

A preliminary concern regarding promoting positive duties to the status of duties of justice is, as we saw, that positive duties might be imperfect. But Narveson himself says that we can improve on the common view that these duties afford agents completely indeterminate latitude. What is really important here is that agents' limited resources be taken into account when deciding what duties to assist others they have. ${ }^{29}$ The relation between costs and benefits of assistance for the agent and the subject can be assessed and reasonable targets (which do not involve sacrificial altruism on the part of the agent) can be identified. Furthermore, institutional mechanisms can be introduced for this purpose, identifying kinds of basic need and circumstances under which persons may be demanded to contribute in significant but nonsacrificial ways. Basic positive duties may be construed as people's duty to do their fair share in contributing to ongoing collective practices of assistance to those in need. The problem then is whether such institutional mechanisms, involving for example compulsory taxation by the state, should be introduced.

Narveson's first consideration here is that informal mechanisms of contribution (such as "charity concerts") "are preferable to compulsory contribution" because they are "[a] more fun than paying taxes, and, [b] being genuinely charitable, also far more recommendable." Narveson also says that [c] these methods "work so well that there would arguably be no need for state support even if there weren't a moral case against it." 30 Con- 
sideration [a] seems quite weak. For some people it might be "more fun" to go to charity concerts than to pay taxes. But proper allocation of tax funds may go a longer way in efficiently channeling funds to satisfy basic needs. Thus the benefit to the needy of the taxation mechanism may be larger. On the other hand, it may be less burdensome to pay taxes than to assist all the charity concerts one would have a duty to go to if one is to seriously discharge one's basic positive duties. Furthermore, reasonable taxation would make sure that every citizen indeed contributes their fair share toward the satisfaction of the basic needs of others. ${ }^{31}$ Consideration [b] is important and hard to disagree with. But just as people may contribute to informal charity funds out of genuine solidaristic motives, so can they pay their taxes out of solidaristic motives. Mixed, or nonsolidaristic motives, can be present in both cases. The decisive consideration here is, in the end, [c]. This is an empirical claim according to which informal charity does more to assist the needy than compulsory taxation. This is an intriguing claim, for which Narveson provides no supporting argument. Overwhelming historical evidence suggests, however, that the introduction of the welfare state in Western countries involved a huge leap forward in terms of satisfaction of basic needs of the population as compared to mere informal charity existing under the previous, more laissez faire forms of capitalism. ${ }^{32}$

So it seems that further argument is needed to show that we do not have reason to promote basic positive duties to the status of duties of justice. In [c] Narveson intimates that a further, "moral case" might be made against compulsory contribution. He immediately says that, actually, there is such a moral case to be made: [d] "Taking involuntarily from Jim to be 'charitable' to Judy is not right; nor is taking from first-world taxpayers in order to feed starving folks on the other side of the globe." Narveson thus rejects the view that "taxpayers' money is up for grabs, to be spent as enlightened intellectuals direct, rather than as the unenlightened earners of that money would spend it if they had their choice." 33

The problem with [d] is, however, that it is obviously question begging. People's absolute right to their pretax income is precisely what Narveson should be trying to prove here. Narveson might revert here to the argument, mentioned above, leading to the libertarian principle of right: everybody would be worse off if there were no prohibition against public encroachment upon their liberty to do as they want with what they possess. But we still need to know whether the interest in not being taxed is among the important freedoms to be protected by the principle of right. Not all freedoms are equally important (or even important at all). Liberals who support public taxation to assist the needy do, for example, recognize a set of liberties 
that must be respected by any state (such as physical integrity, freedom of the press, of political participation, of association, of religion, and so on). ${ }^{34} \mathrm{~A}$ separate argument is needed to show that people's interest not to be taxed is more important than the interest in there being public institutions securing reasonable (nonsacrificial) contribution to those in dire need. Since people obviously have an important interest in being assisted by others in situations of dire need, a contractarian argument balancing the relative weight of this interest against the interest in not being taxed is needed. I turn now to what that argument might be.

\subsection{Baselines, bargaining power, and abstraction}

Does the inconvenience of being taxed (assuming that taxation is progressive, exacting more from those who have more, and focused on basic assistance to those in need) have more weight than the security that one's basic needs would be met if one could not satisfy them on one's own? Narveson indeed claims that a "social contract" would recognize the importance of duties to aid the needy. But he does not think such duties would be duties of justice, because some people's position would be severely worsened by compulsory contribution. To see whether this argument works, we need to make explicit what the conditions of bargaining within the game of mutual advantage contractarianism are.

Larry Temkin correctly points out that Narveson fails to address the crucial problems of justifying the relative positions of power of bargainers and the baselines of comparison of options when setting up a contractarian argument. ${ }^{35}$ In what follows I will further argue that Narveson actually operates with different descriptions of the parameters of bargaining in different cases. This is not surprising for, as I will show, Narveson is bound to face a devastating dilemma: the more information about their situation bargainers are allowed to use in their deliberations, the less likely the social contracts are to even yield negative duties, whereas the less information bargainers can rely on, the more likely the social contracts are to yield basic positive duties of justice.

In his argument defending the existence of basic positive duties as informal duties of virtue, Narveson claims that all rational persons recognize that they might face situations in which they will not be able to satisfy their basic needs on their own:

The cliché says "You never know"-but like so many clichés, it has truth. We are all vulnerable to accident, disease, and what-haveyou, and there's a fair chance that we will need somebody's help, without room for commercial arrangement. ${ }^{36}$ 
The truth in the "You never know" cliché makes it rational even for wealthy people to endorse a norm demanding help to those in need. But why not take this norm as the basis for the construction of a claim of justice? If everyone faces "a fair chance" of needing basic objects whose supply they can not secure by means of commercial arrangements, why not set up a regime in which those who can contribute to the provision of those objects at no grievous cost to themselves are compelled to do so? Would not this be a prudent choice for all? Narveson's only way to reject this proposal is by means of appealing to the different ex ante positions of the bargainers partaking in the "social contract." He proposes that we see them as following "The Silver Rule" which includes consideration of "the likelihood that we will be in situations where others could help us, as well as the likelihood that we will be in situations where we could help." ${ }^{37}$ Since very wealthy and strong people know that the likelihood of needing help for which they cannot pay is very low, and the likelihood of being able to provide it to others at no grievous cost to themselves is very high, they normally will, if they are self-interested, reject a compulsory system of contribution and opt instead for an informal, voluntary one.

Now, if the Silver Rule is to be taken to heart, then it is not clear that the strong and wealthy would accept a far-reaching principle of right prohibiting all kinds of significant harm, including the prohibition to seize others' property. There might be cases in which they would benefit more from harming the poor and weak than from setting up cooperative ventures with them. ${ }^{38}$ Even if they seriously looked for social arrangements based on mutually advantageous rational agreement with those relevantly affected, they need not be rationally moved to look for the ones envisaged by libertarians. Assume that $A$ is quite wealthy and strong and that $B$ is quite poor and weak. Since $B$ would neither be able to greatly benefit nor seriously harm $A$, it is not obvious that $A$ would rationally agree to rule $\mathrm{R}$ if $\mathrm{R}$ demands $A$ not to harm $B$ in any significant way. $A$ would be worse off under $\mathrm{R}$ than under an alternative rule $\mathrm{R}^{*}$ allowing them to seize some of the resources controlled by $B$. $A$ can get $B$ to agree to $\mathrm{R}^{*}$ by saying to $B$ that unless $B$ goes along with $\mathrm{R}^{*}$ $A$ is prepared to follow an even harsher rule $\mathrm{R}^{* *}$ under which $A$ seizes even more of the resources controlled by $B$.

Knowing that the likelihood of their being the object of certain harms is very low, and the likelihood of their getting away with doing the harm themselves is very high, the strong and wealthy might rationally settle for arrangements of right giving them special entitlements denied to the weak and poor (at least for as long as their power supremacy is certain). In other words, if we grant bargaining agents full appeal to their ex ante power, the bargaining game need not yield "social contracts" prohibiting all forms of significant harm. Libertarian- 
ism might not be the outcome of mutual advantage contractarianism.

Narveson might reply that a less than far-reaching principle of right granting disproportionate prerogatives to the powerful would not be acceptable because it would worsen the condition of the weak who become the target of permitted harm. But this answer would take for granted the current status quo as the baseline of comparison. The powerful (and, with different aims, the weak and poor) would say that a real bargain does not merely compare a current scheme with a feasible alternative, but all feasible alternatives (including the current scheme) at once. Narveson provides no argument for convincing the powerful bargainer that their rebuttal is inadequate. ${ }^{39}$

The only way for Narveson to overcome the challenge posed by the powerful is by increasing the abstraction in the description of the conditions of bargaining. On one occasion, Narveson says that bargaining is "impartial," meaning that bargainers deliberate without knowing which side in the bargain they really represent. Thus, in his criticism of egalitarianism, Narveson says that egalitarianism, in recommending scheme (2) instead of scheme (1) (see chart below), "violates impartiality." "On an impartial view of the matter, where the choosers did not know whether they were in position of person $A$ or of person $B$, and if the choice were exclusively between (1) and (2), it would clearly be wrong to choose (2)." ${ }^{\circ}$

\begin{tabular}{|c|c|c|}
\hline & $A$ & $B$ \\
\hline$(1)$ & 4 & 6 \\
\hline$(2)$ & 3 & 3 \\
\hline$(3)$ & 4.5 & 5.5 \\
\hline$(4)$ & 4.4 & 10 \\
\hline$(5)$ & 4.5 & 9.9 \\
\hline
\end{tabular}

Note: (1) through (5) are feasible basic distributive schemes. $A$ and $B$ are the recipients. The chart shows what would be the payoffs obtained by $A$ and $B$ under the different schemes, assuming that $A$ and $B$ are self-interested and discounting their comparative preferences. Assume, throughout, that 4.5 is the threshold of basic needs satisfaction.

Disregarding Narveson's obvious misinterpretation of what egalitarians claim, ${ }^{41}$ it is clear that this clause assuming ignorance would not only make bargainers avoid schemes involving significant harm but would also make it pretty hard for them not to see it as rational to accept a distributive scheme under which basic positive duties of justice are recognized. ${ }^{42}$ Assume that the comparison is now between schemes (1), (2), and (3). 
Certainly it is irrational to choose (2) over (1), as (2) would be worse for all. But, would it be irrational to choose (3) over (1)? Moving from (1) to (3) involves worsening the condition of $B$, whereas moving from (3) to (1) involves worsening the condition of $A$. Unless we take the status quo (be it (1) or (3)) for granted (which we cannot when we are determining, at an abstract level, the basic rules of a regime of cooperation), it seems that the choice between (1) and (3) is, in terms of Pareto, indeterminate: what is rational for $A$ is irrational for $B$ and vice versa. Assume now, however, that the bargainers do not know whether they represent $A$ or $B$, and that they know that 4.5 is the threshold of basic needs satisfaction. Would it not be rational for a bargainer, so described, to choose (3)? If the bargainer winds up being $A$, they will have made sure that they will not face starvation, homelessness, or easily curable mortal diseases. If the bargainer winds up being $B$, they may not be as satisfied as they could have been under (1), but the risk of being destitute was pretty real, and it has been avoided while ending up in a condition that is not so bad after all. Choosing (3) as a regime of justice, sustained by coercive taxation if necessary to secure its fulfillment, is the rational choice here. The reason is, of course, that avoiding life threatening poverty is an urgent interest (almost) any rational agent has.

To conclude, it is not clear that the strong libertarian principle of right would be selected by rational bargainers. The principle says that no basic positive duty can be enforced and that no encroachment upon negative liberty can be permitted (except as a response to harmful actions). However, if we allow bargainers full access to their differential situations (including their bargaining power and all feasible distributive schemes available), then some alleged negative duties will not be protected. If, alternatively, we restrict the information available to bargainers to secure impartiality in their negotiations, then some positive duties will be seen as worthy of enforcement. Either way, the libertarian principle of right prohibiting all encroachment upon individuals' negative liberty will not be the focus of rational agreement.

Narveson's libertarian case against basic positive duties of justice therefore fails. He can only deny that basic positive duties are duties of justice by allowing bargainers to mobilize the full spectrum of their power and information. But this, as we saw, blocks the justification of the sweeping libertarian principle of right prohibiting all interference with negative liberty. Narveson can attempt to short-circuit permissions of encroachment upon negative liberty by denying bargainers full access to their situational circumstances. But this, as we saw, would make it rational for them to accept basic positive duties as duties of justice and thus, again, to reject the sweeping libertarian principle of right. 


\subsection{Basic positive duties and global justice}

The claim that $A$ has a basic positive duty of justice to do their fair share in aiding $B$ entails (a) that $A$ is relatively well off and $B$ faces destitution; (b) that avoiding destitution is an urgent interest of (almost) any human being; and (c) that $A$ can do their fair share to contribute to the satisfaction of $B$ 's basic needs without grievous sacrifice. Given these conditions, it makes sense to say that $B$ has a right to $A$ 's assistance. This right may be said to connect with only an imperfect duty on the part of $A$. However, as we saw, an institutional structure can be developed so that the general collective duty of all those in a position like $A$ toward all those in a position like $B$ can be specified in a set of clearly delimited perfect duties. Now, can this cluster of duties be said to have global scope? The enormous technological capabilities and accumulated wealth in our contemporary world, coupled with the increasing inequality in their distribution, and the fact that 18 million people die each year due to povertyrelated causes make this question very pressing. ${ }^{43}$

As we saw, Narveson does not think that assistance need stop at national boundaries. "The thesis that fellow-countrymen, just as such, are more deserving of life-saving aid than others is prima facie incredible, and morally absurd." ${ }^{44}$ Narveson does have, however, at least three arguments against the claim that there are global basic positive duties of justice. I will close this paper by showing that none of them works.

The first concern is that aid to distant others might be quite burdensome to the duty-bearers. Narveson complains about those who ask the world's rich to "shell out quite a lot of money to the cause of handouts to the world's badly-off," or call for a "huge" "redistribution" of resources. ${ }^{45}$ If assistance involved grievous costs, then condition (c) as stated above would not be met, and thus no basic positive duties could arise here. However, the eradication of severe poverty would actually be quite cheap. According to Thomas Pogge's calculation, for example, sufficient resources to eradicate severe poverty could be obtained if the global rich gave up just 1.2 percent of their annual aggregate income for some years. ${ }^{46}$ The situation we face is akin to one of moving from scheme (4) to scheme (5) (see the chart), which involves no serious dent in the budget of the global rich. An impartial social contract could hardly find this move inappropriate.

A second complaint by Narveson is that global positive duties of the sort discussed here cannot be duties of justice (even if they were duties of virtue). The reason is that positive contribution to others can only be enforceable if it is a form of "restitution" for harms done. But we, the world's rich, do not have such a duty, because “our distant sufferers aren't so because we made them so." 47 The causes of severe poverty are largely 
endogenous to poor countries. There are two serious problems with this argument. The first is that it assumes the sweeping libertarian principle of right, for which Narveson, as we saw, did not succeed at providing a compelling case. A second problem is that, even if we see positive contribution as indirectly grounded in negative duties not to harm, it is hardly true that the global rich have not been seriously involved in harming the global poor. Even if Narveson were right that destitution in poor countries primarily results from their governments' inefficient and corrupt policies and their lack of encouragement of endogenous productive and commercial practices, it would be a mistake to think that the world's rich are not implicated. The latter are involved in a number of ways. Pogge's recent work is, again, quite illuminating in this respect. According to Pogge, the global rich have been shaping the international political and economic environment that makes it possible and desirable for corrupt elites in poor countries to proceed as they do. Two features of that order are what Pogge calls the "international borrowing privilege" and the "international resource privilege" (under which authoritarian elites in poor countries are internationally allowed, and even encouraged, to appropriate and sell the natural resources of the countries they rule, and contract public debt in their people's name, with crippling political and economic consequences). ${ }^{48}$ Furthermore, Narveson builds an artificial opposition between government and business, seeing the former as the main party responsible for harm to the poor and the latter as their "savior." 49 There is ample evidence that some sectors of the international business community have supported harmful corrupt governments. ${ }^{50}$

A final concern raised by Narveson is that "even if enforced charity were justified, it would be unnecessary." ${ }^{1}$ The solution to world poverty is not foreign aid, as it tends not only to involve stealing from the well-off, but also an inefficient hampering of spontaneous economic development in poor countries. Foreign aid (i) "puts the money at the mercy of the recipient government -not the intended people;" (ii) is controlled by inefficient bureaucracies that do not know what the best allocation of resources would be; and (iii) unfairly subsidizes some sectors of the economy at the expense of others. "The sensible, and only really satisfactory alternative to schemes of 'foreign aid' is the free market." 52 "Insofar as we can speak of a 'problem' of poverty in the world, its solution certainly lies with the business community." 53

This final complaint by Narveson involves at least two mistakes. First, it is certainly true that "foreign aid" may be used inefficiently, cementing the rule of corrupt elites and failing to nourish "grassroots" small business and civil society. But no serious advocate of foreign aid would quarrel with this claim and would certainly ask for "smart" forms of aid precisely 
targeting small business and civil society. Second, it is dubious that unrestricted free market is the panacea for the elimination of severe poverty. Controlling markets was necessary for limiting the spread of poverty in Western industrialized societies and would be no less necessary at the global level. Actually, radical forms of "liberalization" of markets in poor countries have increased, not reduced, the levels of destitution. ${ }^{54}$ On the other hand, Narveson recognizes that rich countries have harmed poor countries by introducing unilateral trade barriers protecting their industries. ${ }^{55}$ But a response to this situation, if it seriously aims at the eradication of severe poverty, need not be a completely "free trade." "Fair trade" may be a better idea, as it would grant poor countries temporary entitlements to protect their emerging industries from devastating competition with industries from more developed countries. "Fair trade," unlike "free trade" would be more efficient in eradicating severe poverty. It would however involve, of course, discharge of positive duties on the part of members of rich countries.

\section{Notes}

1 Research for this paper has been supported by grants from the Social Sciences and Humanities Research Council of Canada and the Fonds Québécois de la Recherché sur la Société et la Culture.

2 I will consider the following four recent texts by Jan Narveson, "Welfare and Wealth, Poverty and Justice in Today's World," Journal of Ethics 8, no. 4 (2004): 305-48; "Is World Poverty a Moral Problem for the Wealthy?" Journal of Ethics 8, no. 4 (2004): 397-408; [3] "Libertarianism," in The Blackwell Guide to Ethical Theory, ed. Hugh Lafollette (Oxford: Blackwell, 2000), 306-24; and "We Don't Owe Them a Thing! A Tough-Minded but Soft-Hearted View of Aid to the Faraway Needy," The Monist 86, no. 3 (2003): 419-33.

3 For a discussion of the difference between "doing one's fair share" assuming that others should do theirs, and doing all that one can when others do not do their part, see Liam Murphy, Moral Demands in Nonideal Theory (Oxford: Oxford University Press, 2000).

4 Two clarifications to avoid misunderstanding. First, I claim that enforceability when necessary to secure fulfillment is in principle a necessary, not a sufficient condition for a duty to be a duty of justice. I do not claim that all legally established duties are duties of justice. Some legally binding duties may be worthy of criticism from the point of view of justice, and some duties of justice may not yet be legally recognized (and should be so recognized, by means of political reform, if legal enforceability is required to secure their fulfillment). Second, my characterization of duties of justice is compatible with recognizing that some duties may be duties of justice and yet should not be held as legally enforceable. There might be, in some circumstances, weighty reasons of justice to avoid coercion to secure compliance with what less weighty reasons of justice would demand. A certain duty may be such that we see it as in principle enforceable but not as being, all things considered, enforceable.

5 For an exploration of this issue, see Elizabeth Ashford, "The 
Duties Imposed by the Human Right to Basic Necessities," in Freedom from Poverty as a Human Right, ed. Thomas Pogge (Oxford: Oxford University Press, forthcoming).

6 The rider "can be agents or subjects to them" is important. A one-year-old child can, for example, be a recipient of the duty to avoid physical harm but cannot be the agent of a duty not to break promises or contracts. For recent overviews of discussions over the cosmopolitan status of duties of justice see Charles Beitz, "Cosmopolitanism and Global Justice," Journal of Ethics 9, no. 1-2 (2005): 11-27, and my "Cosmopolitanism and Discourse Ethics. A Critical Survey," New Political Science 28, no. 1 (2006): 1-21.

7 For powerful accounts of the route from recognition of basic socioeconomic rights to institutional structures specifying correlative duties see Henry Shue, "Mediating Duties," Ethics 98 (1988): 687-704; Cécile Fabre, Social Rights Under the Constitution (Oxford: Oxford University Press, 2000), and James Nickel, "Poverty and Rights," Philosophical Quarterly 55, no. 220 (2005): 385-402.

8 Robert Nozick, Anarchy, State, and Utopia (New York: Basic Books, 1974), 163.

9 Ibid., 160.

10 The most thorough discussion of Nozick's libertarianism is Gerald Cohen's Self-ownership, Freedom and Equality (Cambridge: Cambridge University Press, 1995). For a comprehensive overview of recent debates on Nozick's libertarianism, see Will Kymlicka, Contemporary Political Philosophy, 2nd ed. (Oxford: Oxford University Press, 2002), 103-27.

${ }^{11}$ Narveson "Welfare and Wealth," 317.

12 Ibid., 305.

${ }^{13}$ Narveson, "We Don't Owe Them a Thing!" 421, 423. Narveson recognizes that assisting others in "dire need" when we can do it without great sacrifice on our part is a moral duty (ibid., 420-4). He insists, however, that we must distinguish between duties of strict justice (all of which are negative or derived from negative duties) and moral duties of virtue. The latter, based on "benevolence," "sympathy," or "charity," do not involve correlative enforceable rights. See Narveson "Welfare and Wealth," 319, 343. We should not "confuse" "moral virtue" with "justice"; "justice does not require that we improve [others'] situation, though sympathy recommends it;" "justice consists in not interfering with the various processes by which people improve their lots" (Narveson, "Is World Poverty a Moral Problem for the Wealthy?" 405, 407).

${ }^{14}$ Narveson discusses these assumptions of public rationality, utility orientation, evaluative disagreement and environmental scarcity ("common sense truths on which general morals is to be based") in Narveson, "Welfare and Wealth," 309-12.

${ }^{15}$ Narveson, "Welfare and Wealth," 321-2.

${ }^{16}$ Ibid., 324, 322.

${ }^{17}$ Ibid., 319.

${ }^{18}$ Ibid., 313-16.

${ }^{19}$ Ibid., 316.

${ }^{20}$ Ibid., 316.

${ }^{21}$ Narveson, "Libertarianism," 306.

${ }^{22}$ Ibid., 314-15. Notice that Narveson uses here the weaker version of the Pareto idea. 
${ }^{23}$ Ibid., 318-19.

${ }^{24}$ Narveson, "We Don't Owe Them a Thing!" 430. Libertarianism's scope is universal. See Narveson, "Libertarianism," 308.

${ }^{25}$ Larry Temkin, "Thinking about the Needy: A Reprise," Journal of Ethics 8, no. 4 (2004): 409-58, at 451.

${ }^{26}$ A typical example of $R^{*}$ is a wealthy society in which there is no public health care and other forms of assistance securing that congenitally handicapped people do not face avoidable death when there are no relatives or charitable organizations supporting them. A typical case of $\mathrm{R}^{* *}$ is an international order that permits multinational corporations to set up "sweatshops" in poor countries. Narveson, at least implicitly, does not find problems with the latter. See Narveson, "Welfare and Wealth, 341-2.

${ }^{27}$ Brian Barry, Justice as Impartiality (Oxford: Oxford University Press, 1995), 46. Barry targets primarily the contractarian conception of justice as presented by David Gauthier in Morals by Agreement (Oxford: Oxford University Press, 1986). Narveson's contractarianism is quite akin to Gauthier's, but since in the texts by Narveson discussed here there is no direct reference to Gauthier, I prefer to limit my discussion to what Narveson himself says.

${ }^{28}$ See John Rawls, A Theory of Justice, rev. ed. (Cambridge, MA: Harvard University Press, 1999), 15-19, 40-6; and Justice as Fairness. A Restatement (Cambridge, MA: Harvard University Press, 2001), 29_ 32 .

${ }^{29}$ Narveson, “We Don't Owe Them a Thing!” 424-5. Narveson's point in his discussion about the identification of the latitude of basic positive duties is, however, unclear. He says that any such duties must give latitude to the agents by means of recognizing the burdens they would have to shoulder when assisting others. But this can be done by careful state legislation no less than by means of individual circumstantial deliberation. Taxation policies always involve conditional clauses, saying that individuals should pay amount $\mathrm{X}$ if their situation (in terms of income, expenses, family size, etc.) is $\mathrm{S}$, and pay $\mathrm{Y}$ if their situation is $\mathrm{T}$, and so on.

${ }^{30}$ Narveson, "We Don't Owe Them a Thing!" 427.

${ }^{31}$ This would not only be good, for obvious reasons, for the recipients of assistance, but it would also ease the moral burden of the duty-bearers, who would not have to get into the trouble of considering whether they should be helping more given the fact that others are not doing their fair share. See on this Ashford, "The Duties Imposed by the Human Right to Basic Necessities."

${ }^{32} \mathrm{An}$ obvious reason is that state intervention, if efficiently organized, helps solve collective action problems. All would be better off if all cooperated in the eradication of poverty (the poor would overcome poverty, the rich would be more secure from political upheaval, all would benefit from a more inclusive economy in which most can work and consume, etc.), but each individually has reason not to cooperate regardless of whether others cooperate. Narveson recognizes the presence of collective action problems with informal, "charity" based schemes of assistance, but thinks that they can be dismissed once we see that the assistance games are iterative rather than "one shot" games. See Narveson, "We Don't Owe Them a Thing!" 429. One can, however, be rather skeptical about the extent to which wealthy people will really seek to voluntarily assist the poor. See on this Brian 
Barry, Why Social Justice Matters (Cambridge: Polity, 2005), ch. 2.

${ }^{33}$ Narveson, "We Don't Owe Them a Thing!" 428. See also Narveson, "Welfare and Wealth," 341, where "aid" as "compulsory assistance" is described as "theft," as it "denies the liberty of the people so compelled."

${ }^{34}$ For an extensive discussion on the differences between liberalism and libertarianism see Samuel Freeman, "Illiberal Libertarians: Why Libertarianism Is Not a Liberal View," Philosophy \& Public Affairs 30, no. 2 (2002): 105-51. On the other hand, it might be relevant to consider the empirical hypothesis that satisfaction of basic needs might reduce the likelihood that people (richer or poorer citizens alike) engage in aggressive violation of generally accepted important liberties.

${ }^{35}$ Temkin, "Thinking about the Needy: A Reprise," 435-37.

${ }^{36}$ Narveson, "We Don't Owe Them a Thing!" 427.

${ }^{37}$ Ibid., 426.

${ }^{38}$ An obvious historical example is the seizing of territory from and the extermination of aboriginal people by European settlers during their bloody conquest of America. See on this Barry, Justice as Impartiality, 41. Contemporary international politics includes less radical, but still quite relevant, examples of unilateral harm. The United States' military interventions and its failure to ratify numerous international treaties limiting pollution and nuclear and biological weapons development might be a good illustration.

${ }^{39}$ In his earlier text The Libertarian Idea (Philadelphia: Temple University Press, 1988), Narveson recognizes that there is a general problem for contractarians to identify just what the relevant baseline of comparison is. He does not, however, provide any clear position in this respect. He mentions (without clearly settling the question) several possible alternatives that might be compared to the libertarian principle of right, such as our current societies as we know them, a status quo of noninteraction, an unruly or "predatory" state of nature, and alternative liberal schemes. See The Libertarian Idea, 154-5, 176, $177,180-1$.

${ }^{40}$ Narveson, "Welfare and Wealth," 323.

${ }^{41}$ Most egalitarians ask for equal access to certain primary goods, not for generalized equal satisfaction or utility, and they accept inequalities that benefit the worse off. Thus, for example, under Rawls's "Difference Principle" (1) would be chosen over (2).

${ }^{42}$ Narveson is coming here dangerously close to Rawls's approach to the "social contract," in which, precisely to secure impartiality, a "veil of ignorance" is introduced. The results from Rawls's "original position" are, of course, incompatible with libertarianism. See Rawls, $A$ Theory of Justice, 130-9.

${ }^{43}$ See Thomas Pogge, "Real World Justice," Journal of Ethics 9, no. 1-2 (2005): 29-53, at 30-2. I defend the claim that there are positive (as well as negative) duties of global justice regarding world poverty in my "The Duty to Eradicate Global Poverty: Positive or Negative?" Ethical Theory and Moral Practice 7, no. 5 (2004): 537-50.

${ }^{44}$ Narveson, "We Don't Owe Them a Thing!" 431.

${ }^{45}$ Narveson, "Is World Poverty a Moral Problem for the Wealthy?" 403, 408.

${ }^{46}$ See Thomas Pogge, World Poverty and Human Rights (Cambridge: Polity, 2002), 7.

${ }^{47}$ Narveson, "We Don't Owe Them a Thing!" 420. 
${ }^{48}$ Pogge, World Poverty and Human Rights, 22-3, 112-16. See also Pogge, "Real World Justice," 47-50. Narveson does recognize that (as Pogge claims) there are some harmful aspects of the current global economic order (especially regarding trade regimes) but does not seriously pursue their pervasive significance and implications. See Narveson, "Welfare and Wealth," 336-7.

${ }^{49}$ See theses [A4] and [A5] above and Narveson, "Is World Poverty a Moral Problem for the Wealthy? 406.

${ }^{50} \mathrm{Or}$ thus argues Transparency International (TI) in its recent "global corruption reports." See http://www.globalcorruptionreport.org/. The chairman of TI, Peter Eigen, claims that "a lot of the responsibility for corruption in the developing world has been with Northern companies and Northern institutions" (quoted in The Guardian Weekly, April 1-7, 2004, p. 3).

${ }^{51}$ Narveson, "We Don't Owe Them a Thing!" 430.

${ }^{52}$ Narveson, "Welfare and Wealth," 340-1.

${ }^{53}$ Ibid., 347.

${ }_{54}$ Typical examples are Eastern Europe and Russia during the 1990 s, and Argentina toward the end of that decade. For a useful overview of relevant contemporary debates on the alternative forms of "globalization," see David Held and Anthony Grew, Globalization / AntiGlobalization (Cambridge: Polity, 2002).

${ }^{55}$ Narveson, "Welfare and Wealth," 336-9. 
Copyright of Southern Journal of Philosophy is the property of Southern Journal of Philosophy and its content may not be copied or emailed to multiple sites or posted to a listserv without the copyright holder's express written permission. However, users may print, download, or email articles for individual use. 